\title{
Trends and spatial variation in water and land footprints of meat and milk production systems in Kenya
}

\author{
Caroline K. Bosire ${ }^{\mathrm{a}, \mathrm{c}, *}$, Joseph O. Ogutu ${ }^{\mathrm{d}}$, Mohammed Y. Said ${ }^{\mathrm{c}}$, Maarten S. Krol ${ }^{\mathrm{a}}$, \\ Jan de Leeuw ${ }^{\mathrm{b}}$, Arjen Y. Hoekstra ${ }^{\mathrm{a}}$ \\ a University of Twente, Twente Water Centre, P.O. Box 217, 7522AE Enschede, The Netherlands \\ ${ }^{\mathrm{b}}$ World AgroforestryCentre (ICRAF), P.O. Box 30677, 00100 Nairobi, Kenya \\ ' International Livestock Research Institute (ILRI), P.O. Box 30709, 00100 Nairobi, Kenya \\ ${ }^{\mathrm{d}}$ University of Hohenheim, Institute for Crop Science, Bioinformatics Unit, 70599 Stuttgart, Germany
}

\section{A R T I C L E I N F O}

\section{Article history:}

Received 17 June 2014

Received in revised form 24 February 2015

Accepted 27 February 2015

Available online $\mathrm{xxx}$

\section{Keywords:}

Water footprint

Land footprint

Livestock production

Meat and milk

Kenya

\begin{abstract}
A B S T R A C T
Global consumption of livestock products is increasing steadily due to human population growth, poverty reduction and dietary changes raising the demand for already scarce freshwater and land resources. Here, we analyze the changes associated with direct and indirect use of freshwater and land for meat and milk production in three production systems in Kenya between the 1980s and 2000s. We use two resource use indicators, the water footprint ( $\mathrm{m}^{3} /$ year) and land footprint (ha), to assess changes in freshwater and land use for cattle, goats, sheep and camels in arid, semi-arid and humid production systems. We estimate actual water and land use using Kenya-wide data for yields, feed composition and feed conversion efficiencies. Our results show that the amounts of freshwater and land resources used for production are determined mainly by production volumes and feed conversion efficiencies. Total water and land footprints of milk production increased for goats, sheep and camels but decreased by half for cattle in arid and semi-arid production systems, in correspondence with similar changes in the total numbers of each livestock species. Green water and grazing land footprints dominated in all production systems due to the predominance of indirect use of water to support forage production. The per unit meat footprint for cattle increased significantly between the 1980s and 2000s in all production systems, due to adverse trends in feed conversion efficiency, while changes in the water and land footprints of other animal products were small, due to modest changes in all influencing factors. In contrast, national average footprints per unit of beef and milk show a modest decrease due to a relative shift of production to the more resource-efficient humid production system. Given the potential increase in demand for livestock products and limited freshwater and land availability, feed conversion efficiencies should be improved by rehabilitating degraded rangelands, adopting improved breeds and using appropriate feed composition.
\end{abstract}

(c) 2015 Elsevier B.V. All rights reserved.

\section{Introduction}

Depletion of natural resources by humans, particularly for food production, is widely recognized as a significant threat to the sustainability of consumption (Chertow, 2000; Bac et al., 2011). Growing resource use intensities have led to groundwater depletion, soil loss, drying up of fresh water reserves and land degradation globally (Meyer and Turner, 1994; Campbell et al.,

\footnotetext{
* Corresponding author at: International Livestock Research Institute (ILRI), P.O. Box 30709, 00100 Nairobi, Kenya. Tel.: +254 721391919.

E-mail addresses: c.k.bosire@utwente.nl (C.K. Bosire), jogutu2007@gmail.com (J.O. Ogutu), m.said@cgiar.org (M.Y. Said), M.S.Krol@utwente.nl (M.S. Krol), J.Leeuw@cgiar.org (J.d. Leeuw), A.Y.Hoekstra@utwente.nl (A.Y. Hoekstra).
}

2005; Oago and Odada, 2007). Despite the mounting physical evidence of environmental degradation, the relation between consumption in specific regions and its impact on the environment in the production areas is usually not well recognised and quantified. Attempts to bridge this knowledge gap has motivated the development of various resource use indicators, such as the water and ecological footprints (Rees and Wackernagel, 1996; Hoekstra and Hung, 2002).

The water footprint is an indicator of water use in relation to the production of consumer goods and is expressed in terms of the water volume evaporated or polluted (Hoekstra et al., 2011). A water footprint is composed of three components: the green, blue, and grey water footprints. The green water footprint refers to the consumptive use of rainwater from lands used for crop production or grazing, while the blue water footprint refers to the 
consumptive use of water from rivers, lakes, wetlands and aquifers. Consumptive water use refers to both the volume of water that evaporates and returns to the same catchment or to the sea and that which is incorporated into pasture and crops. The green water footprint is relevant in both rain-fed and irrigated agriculture, while the blue water footprint refers to water consumption in irrigated agriculture as well as in households and industries.The grey water footprint is an indicator of water pollution and refers to the volume of water that is required to assimilate pollutants such as fertilizers, in mainly industrial production systems, in order to meet water quality standards. The water footprint of a live animal consists of two components: the direct water footprint related to the drinking water and service water consumed and the indirect water footprint of the feed (Chapagain and Hoekstra, 2003). The land footprint is defined here as the 'actual land used' for producing consumer goods and services (Erb, 2004). We distinguished between two components: the cropland footprint and the grazing land footprint. The land footprint is similar to the more widely known ecological footprint and only differs in its representation of land use in terms of actual hectares (ha) instead of normalized 'global hectares' (gha) (van Vuuren and Smeets, 2000; Wackernagel et al., 2004). Land appropriation is typically measured across five distinct land use types: cropland, grazing land, fishing ground, forest land, and built-up land.

The use of these indicators in isolation has led some authors to question their usefulness (Fiala, 2008; Vanham and Bidoglio, 2013). This criticism can be addressed by assessing both indicators rather than just one of them. Only few studies have so far combined the water and ecological or land footprints (Hubacek et al., 2009; Ewing et al., 2012). Yet analyzes employing such a combination may enhance their effectiveness in sharpening our understanding of resource use dynamics and possible trade-offs (Hoekstra and Wiedmann, 2014).

The footprint indicators have been applied at various spatial and temporal scales to quantify the demand exerted by humans on natural resources (Wackernagel et al., 1999; Monfreda et al., 2004; Moran et al., 2008; Chapagain and Hoekstra, 2011; McMichael and Butler, 2011; Mekonnen and Hoekstra, 2011). These studies aim to uncover the indirect effect of consumers on the environment. Though thorough, these studies often only provide general overviews of human appropriation of freshwater and land, and only a few account for the local heterogeneity inherent in resource utilization (Ridoutt et al., 2011) and consider the changes over time in water and land footprints per unit of production (Zoumides et al., 2014).

In Kenya, meat and milk production shows spatial variation driven principally by climate related agricultural production potential and associated land use. Market-oriented milk production primarily occurs in high altitude areas, usually classified as the humid production system (Ngigi, 2005). The latter production system constitutes the main dairy production areas in Kenya, where production is mainly by smallholder dairy farms and market oriented. The dairy herds comprise mainly exotic-local breed crosses and the feeding system is largely cut-and-carry and dominated by the use of Napier grass (Pennisetum purpureum) (Thorpe et al., 2000; FAO, 2005). On the other hand are the arid and semi-arid lands (ASAL) production systems in which about $70 \%$ of livestock is reared and where the main feeding system is extensive grazing. The production in these systems is mainly for subsistence, with milk supply being the prime production objective. Even so, cattle offtake for beef marketing still accounts for a large proportion of total output in these systems (Grandin, 1988; Aklilu et al., 2002; Onono et al., 2013). About $22 \%$ of the cattle offtake within this system relates to imported cattle from neighboring countries (Behnke and Muthami, 2011). However, increasing water scarcity and changing land tenure arrangements in these systems progressively hinder optimal use of the expansive land resources available in these pastoral production systems. So far, there has not been any study focusing on the spatial variation in the use of freshwater and land across these production systems in Kenya.

The expected change over time is intensification in both meat and milk production, a common outcome of interventions aimed at integrating rural within national economies. In Kenya, cattle breeding programs initially focused on improving beef cattle to meet rising demands for beef under the Kenya Beef Industry Development Project (Kosgey et al., 2011). This involved crossing the indigenous Zebu or Boran cattle with the exotic Simmental, the dual purpose Sahiwal and improved Boran breeds. After independence in 1963, most of these programs broke down or were abandoned and emphasis shifted to smallholder dairy production in the humid areas. This involved cross-breeding the exotic Friesian, Ayrshire, Guernsey and Jersey breeds with the indigenous cattle breeds, thereby increasing - the milk yields of the latter breeds in the humid systems. The intensification of production necessitated by the improved breeds usually entails the use of elevated levels of input,putting greater strain on the available natural resources (Erb, 2004). Given the prevailing scarcity of resources, the increasing demand for livestock products and the drive for intensification, especially in developing countries, there is undoubtedly a need for increased efficiency in resource use. An assessment of the changes in efficiency of production practices undertaken to meet the growing demands in these systems is thus an essential first step in designing strategies for improving their efficiencies.

In this paper we use the water and land footprint indicators to explore spatial and temporal changes in the use of freshwater and land resources for meat and milk production in Kenya. We also assess the factors constraining efficiency across the production systems between two periods, 1980s and 2000s. We then outline how production parameters govern the use of freshwater and land resources and, finally, make recommendations on ways to improve efficiency in water and land use.

\section{Methods and data}

Our analysis proceeds in four phases. As Kenyan production systems can be divided into distinct geographical zones in terms of agro-ecological characteristics, the main livestock product, the scale of production and husbandry technique, we first delineate the various production systems in Kenya. Secondly, we estimate the number of animals and the volumes of meat and milk production in each of the production systems. The third stage involves the assignment of feed estimates to the various livestock species within the various production systems. Finally, we determine the water and land footprints of meat and milk production per production system in the 1980s (1977-1990) and 2000s (2001-2012), and analyze the changes that have occurred over this period.

\subsection{Characterizing the production systems}

Robinson et al. (2011) give a literature overview of different classification schemes of livestock production systems. In this study, we distinguish three broad categories based on a combination of agro-ecological factors and production patterns: humid, semi-arid and arid production systems (Pratt and Gwynne, 1977; Grandin, 1988; Rege, 2001).

Humid production systems are located in areas receiving an average rainfall exceeding $800 \mathrm{~mm}$, have soils of high fertility and hence high potential for biomass production and modest pest and disease problems. In Kenya, this category covers the areas in Central Kenya, the Central Rift Valley to Western Kenya and most of 
the Coastal strip (Ouma et al., 2000). The semi-arid production system has an average annual rainfall between 600 and $800 \mathrm{~mm}$, a medium potential for biomass production and livestock production is hindered by the prevalence of trypanosomiasis. The areas covered by this production system are located in parts of Southern and Eastern Kenya, areas neighboring the humid production systems to the north and south and the coastal strip. The last system, the arid production system, has an average annual rainfall of less than $600 \mathrm{~mm}$, a low potential for biomass production and livestock production is hindered by the prevalence of various diseases (Grandin, 1988; De Leeuw and Rey, 1995; Ndambi et al., 2007). Biomass production varies greatly across the systems from $25 \mathrm{~kg} / \mathrm{ha}$ in the humid systems to as low as $8 \mathrm{~kg} / \mathrm{ha}$ in the arid system (Ouda, 2001). Per production system, we identified the areas within Kenya where the system occurs and collected relevant data, such as livestock densities, production estimates and diets.

\subsection{Livestock numbers in each production system}

Livestock densities in the arid and semi-arid production systems were estimated from the aerial survey monitoring data collected by the Kenya Directorate of Resource Surveys and Remote Sensing (DRDRS) covering 1977-2012 as part of an ongoing Kenyawide rangeland monitoring program, described previously by Norton-Griffiths (1975) and Ottichilo et al. (2000). Flight transects were oriented in an east-west or north-south direction depending on the terrain. The altitude of the survey flights averaged about $120 \mathrm{~m}$ above the ground. Two experienced and well trained rear seat observers count animals located between the rods attached to the wing struts of the airplane. Groups of more than 10 animals were photographed and later counted using an overhead projector.

DRSRS has conducted more than 272 aerial surveys in 22 administrative counties of Kenya that fall within the arid and semi- arid regions. The surveys cover some $437,000 \mathrm{~km}^{2}$. We obtain the net area of $437,000 \mathrm{~km}^{2}$ by deducting $75,000 \mathrm{~km}^{2}$ designated as protected areas in which livestock access is explicitly prohibited from the total area survey by DRSRS of $512,000 \mathrm{~km}^{2}$ (Bertzky et al., 2012).

Population estimates were calculated using Jolly's Method 2 (Jolly, 1969). Population size estimates and the density (number/ $\mathrm{km}^{2}$ ) of each livestock species were averaged per grid cell ( 5 by $5 \mathrm{~km}^{2}$ ) over the two time periods spanning 1977-1990 (1980s) and 2001-2012 (2000s) in order to minimize the stochastic variation in the individual survey counts.

For the humid production system, a dataset on dairy production in the Kenyan highlands collected in 2005 and considered representative of intensive smallholder dairy production was used (Waithaka et al., 2006). We derived the 1980s livestock estimates using proportional contribution to total livestock numbers by each production system from Behnke and Muthami (2011). To ensure consistency in reporting of outputs per unit area, the Geographic Information System (GIS) spatial layers of the production system and smallholder dairy were overlaid to extract data on the numbers of dairy cows in the production system in 2005. To estimate the number of dairy cows in the herd for both datasets, the dominant breeds of cattle and milk production for each of the three production systems, all the parameters defining herd composition and milk output per breed were extracted from the literature (De Leeuw and Wilson, 1987; Staal et al., 2001; Bebe et al., 2003; Bouwman et al., 2005; Ngigi, 2005).

\subsection{Estimating the total annual production of animal products}

Various parameters from published studies and gray literature were used to estimate both meat and milk production in each of the three production systems (Table 1 ). The data were then used to

Table 1

Parameters used to calculate annual production in three Kenyan production systems.

\begin{tabular}{|c|c|c|c|c|c|c|c|c|c|c|c|c|c|c|c|c|c|c|}
\hline \multirow{3}{*}{$\begin{array}{l}\text { Parameters } \\
\text { Production System }\end{array}$} & \multicolumn{18}{|c|}{ Livestock type } \\
\hline & \multicolumn{6}{|l|}{ Cattle } & \multicolumn{6}{|l|}{ Shoats } & \multicolumn{6}{|l|}{ Camel } \\
\hline & \multicolumn{2}{|l|}{ Arid } & \multicolumn{2}{|c|}{ Semi-arid } & \multicolumn{2}{|l|}{ Humid } & \multicolumn{2}{|l|}{ Arid } & \multicolumn{2}{|c|}{ Semi-arid } & \multicolumn{2}{|l|}{ Humid } & \multicolumn{2}{|l|}{ Arid } & \multicolumn{2}{|c|}{ Semi-arid } & \multicolumn{2}{|l|}{ Humid } \\
\hline Period & $1980 s$ & $2000 s$ & $1980 s$ & $2000 s$ & $1980 s$ & $2000 s$ & $1980 \mathrm{~s}$ & $2000 s$ & $1980 \mathrm{~s}$ & $2000 s$ & $1980 s$ & $2000 s$ & $1980 s$ & $2000 s$ & $1980 s$ & $2000 s$ & $1980 s$ & $2000 s$ \\
\hline $\begin{array}{l}\text { Average number } \\
\left({ }^{(000 s)^{1}}\right.\end{array}$ & 3126 & 1894 & 1757 & 1735 & $2093^{a}$ & 1638 & 6800 & 7324 & 1743 & 2209 & $1056^{\mathrm{b}}$ & $1178^{c}$ & 718 & 685 & 7 & 9 & 0 & 0 \\
\hline $\begin{array}{l}\text { Area of production } \\
\text { system (ha) }\end{array}$ & 41,510 & 41,510 & 8370 & 8370 & 7210 & 7210 & 41,510 & 41,510 & 8370 & 8370 & 7210 & 7210 & 41,510 & 41,510 & 8370 & 8370 & 7210 & 7210 \\
\hline $\begin{array}{l}\text { Average density } \\
\left(\mathrm{TLU}^{*} / \mathrm{ha}\right)\end{array}$ & 18 & 11 & 53 & 52 & 73 & 57 & 41 & 44 & 52 & 66 & 37 & 41 & 4 & 4 & 0.2 & 0.3 & 0 & 0 \\
\hline Offtake rate $(\% / y r)^{3}$ & 0.09 & 0.1 & 0.09 & 0.1 & 0.079 & 0.079 & 0.26 & 0.25 & 0.26 & 0.25 & 0.33 & 0.3 & 0.017 & 0.017 & 0.017 & 0.017 & 0 & 0 \\
\hline $\begin{array}{l}\mathrm{FCE}_{\text {meat }}(\mathrm{kg} \text { feed DM/ } \\
\quad \mathrm{kg} \text { meat })^{3}\end{array}$ & 155 & 175 & 155 & 175 & 54 & 56 & 24 & 27 & 24 & 27 & 23 & 24 & 100 & 100 & 100 & 100 & 0 & 0 \\
\hline Average lifetime (yr) & 6 & 6 & 10 & 10 & 10 & 10 & 3 & 3 & 3 & 3 & 3 & 3 & 6 & 6 & 6 & 6 & 0 & 0 \\
\hline $\begin{array}{l}\text { Carcass yield (kg/ } \\
\text { animal) })^{3}\end{array}$ & 127 & 76 & 127 & 76 & 152 & 247 & 13 & 12 & 13 & 12 & 9 & 12 & 233.4 & 233.4 & 233.4 & 233.4 & 0 & 0 \\
\hline $\begin{array}{l}\text { Proportion of dairy } \\
\text { cattle (\%) }\end{array}$ & $40^{4}$ & $40^{4}$ & $40^{5}$ & $40^{5}$ & $54^{6}$ & $54^{6}$ & $40^{4}$ & $40^{4}$ & $40^{5}$ & $40^{5}$ & $40^{5}$ & $40^{5}$ & 42 & 42 & 42 & 42 & 0 & 0 \\
\hline $\begin{array}{l}\text { Milk yield (kg/year/ } \\
\text { animal) })^{3}\end{array}$ & 462 & 328 & 462 & 328 & 662 & 1055 & 69 & 69 & 69 & 69 & 0 & 0 & 547 & 547 & 547 & 547 & 0 & 0 \\
\hline $\begin{array}{l}\mathrm{FCE}_{\text {milk }}(\mathrm{kg} \text { feed DM/ } \\
\quad \mathrm{kg} \text { milk })^{3}\end{array}$ & 4.8 & 4.6 & 4.8 & 4.6 & 3.4 & 3.1 & 0.33 & 0.33 & 0.33 & 0.33 & 0.33 & 0.33 & $6.4^{7}$ & $6.4^{7}$ & $6.4^{7}$ & $6.4^{7}$ & 0 & 0 \\
\hline Average lifetime (yr) & 12 & 12 & 10 & 10 & 10 & 10 & 3 & 3 & 3 & 3 & 3 & 3 & 10 & 10 & 10 & 10 & 0 & 0 \\
\hline
\end{tabular}

* $1 \mathrm{TLU}=250 \mathrm{~kg}$.

${ }^{1}$ Department of Resource Surveys and Remote Sensing (DRSRS) (Ogutu et al., in press) where a, b and c are livestock numbers derived from the DRSRS estimatesusing proportions of the total population in a given period as in Behnke and Muthami (2011).

2 GIS maps of production system.

3 Bouwman et al. (2005).

4 De Leeuw and Wilson (1987).

5 Behnke and Muthami (2011).

6 Staal et al. (2001).

7 Hashi, Kamoun et al. (1995). 
quantify the products, the output of each product per animal and per unit of land area. We assume that there is no milk production by sheep and goats (lumped together during aerial surveys and referred to as 'shoats' throughout this paper) in the humid production systems.

The total annual production of meat in each production system was then calculated as follows. The meat production $\left(P_{\text {meat }}[a, s]\right.$, ton/yr) per animal in category $a$ (beef cattle, camel, sheep and goat) in production system $s$ (arid, semiarid, humid) is estimated by multiplying the carcass yield per slaughtered animal $(\mathrm{CY}[a, s])$ by the annual number of animals slaughtered $(\mathrm{SA}[a, s])$ :

$P_{\text {meat }[a, s]}=\mathrm{CY}[a, s] \times \mathrm{SA}[a, s]$

The carcass yields for cattle and shoats were obtained from Bouwman et al. (2005).

The number of animals slaughtered in each production system was calculated by multiplying the total animal numbers Pop $[a, s]$ by the net offtake rate OR[a,s]:

$\mathrm{SA}_{[a, s]}=\operatorname{Pop}[a, s] \times \mathrm{OR}[a, s]$

Data on offtake rates were applied as a net offtake rate following Bouwman et al. (2005).

Total annual milk production (tonne) per animal for each production system was calculated as follows:

$P_{\text {milk }}[a, s]=\operatorname{MY}[a, s] \times \operatorname{DC}[a, s]$

where $P_{\text {milk }}$ represents the production of milk per cow or shoat in production system $s, \mathrm{MY}[a, s](\mathrm{kg})$ is the milk yield per dairy cow in each production system and $\mathrm{DC}[a, s]$ is the number of dairy cows in each production system, resulting from the total number of cows and the proportion of lactating cows from Table 1 . The yield estimate is derived by assigning the yield attributed to the predominant breed i.e., Zebu, crossbreed or exotic, as the milk yield estimate within a specific production system (King, 1983; Rege, 2001; Staal et al., 2001; Ngigi, 2005).

\subsection{Volume and composition of feeds}

The diet of livestock in Kenya varies widely and depending on the agro-ecology as well as the type and level of intensification of the production system (Owen et al., 2004). To estimate the spatial distribution of feed demand, a method that allows the prediction of daily feed intake by using information on diet composition and quality, feed conversion efficiency and milk and/or meat production was employed. The estimation of quantities of feed, feed composition, sources of feed and feed yields per unit area within each production system was made by combining parameters from the literature (Tables 1,2), with the estimates of livestock numbers in (Table 1).
To estimate the feed volume in each system, a relationship linking the feed conversion factor of the production system to the product output was developed (Greer and Thorbecke, 1986):

Feed $_{[a, s]}=\operatorname{FCE}_{[a, s]} \times P_{[a, s]}$

Feed $_{[a, s]}$ (ton/yr) is the total amount of feed consumed by an animal in category $a$ in production system $s, \operatorname{FCE}_{[a, s]}$ is the feed conversion efficiency ( $\mathrm{kg}$ dry mass of feed/ $\mathrm{kg}$ product) for animal $a$ in production system $s$ and $P_{[a, s]}(\mathrm{kg} / \mathrm{yr})$ is the amount of product (milk, meat) produced by animal $a$ in production system $s$. The feed conversion efficiencies for the 1980s and 2000s were taken from Bouwman et al. (2005) and represent aggregate values.

We distinguish the feeds into four classes: (i) pasture, which includes hay and silage; (ii) planted forage; (iii) crop residues; and (iv) compounded feed and supplements. The feed composition in the humid system for cattle, which focuses on dairy, was obtained from studies carried out at six sites within the East African Dairy Development project that estimated feed composition in this production system (ILRI, 2010). For the pastoral systems - arid and semi-arid - we assumed that livestock diet is derived solely from natural grazing resources for the 1980s. In the semi-arid production system feed composition for the 2000s, we assume a proportion of crop residue in the diet. In-depth analysis of the dietary composition was not possible due to the large area covered in this study and the broad array of plant forage species, both of which complicate collection of reliable information on the species composition of the forage plants.

\subsection{Water and land footprints calculations}

\subsubsection{Water footprints of livestock products}

For beef cattle, the calculation of water footprint is most useful when an animal is considered at the end of its lifetime, because it is this total that will be allocated to the various resulting products (e.g., meat, leather). For dairy cattle, it is most straightforward to look at the water footprint of the animal per year, averaged over its lifetime, because one can easily relate this annual animal water footprint to its average annual milk production (Mekonnen and Hoekstra, 2010b). Therefore, the water footprint of an animal can be expressed in terms of $\mathrm{m}^{3} / \mathrm{yr} / \mathrm{animal}$, or, when summed over the lifetime of the animal, in terms of $\mathrm{m}^{3}$ /animal. The water footprint of an animal can thus be expressed as:

$\mathrm{WF}[a, s]=\mathrm{WF}_{\text {feed }}[a, s]+\mathrm{WF}_{\text {drinks }}[a, s]+\mathrm{WF}_{\text {serv }}[a, s]$

where $\mathrm{WF}_{\text {feed }}[a, s], \mathrm{WF}_{\text {drinks }}[a, s]$ and $\mathrm{WF}_{\text {serv }}[a, s]$ represent the water footprint of an animal in category $a$ in production system $s$, related to feed, drinking water and service water consumption, respectively; the feed water footprint generally dominates the other components by far. Service water refers to the water used for cleaning the area occupied by the animals, washing the animal and carrying out other services necessary to maintain the environment.

Table 2

Feed composition for cattle, shoats and camel in three Kenyan production systems in the 1980s and 2000s.

Source: East Africa Dairy Development Project Report 2010 (ILRI, 2010) and Ben Lukuyu (Pers.com). Where "0"represents no feed of that category in the diet.

\begin{tabular}{|c|c|c|c|c|c|c|c|c|c|c|c|c|c|c|c|c|c|c|}
\hline \multirow{3}{*}{$\begin{array}{l}\text { Parameters } \\
\text { Livestock type } \\
\text { Production system } \\
\text { Time frame }\end{array}$} & \multicolumn{6}{|c|}{$\begin{array}{l}\text { Production system and livestock species } \\
\text { Cattle }\end{array}$} & \multicolumn{6}{|l|}{ Shoats } & \multicolumn{6}{|l|}{ Camel } \\
\hline & \multicolumn{2}{|l|}{ Arid } & \multicolumn{2}{|c|}{ Semi-arid } & \multicolumn{2}{|c|}{ Humid } & \multicolumn{2}{|l|}{ Arid } & \multicolumn{2}{|c|}{ Semi-arid } & \multicolumn{2}{|l|}{ Humid } & \multicolumn{2}{|l|}{ Arid } & \multicolumn{2}{|c|}{ Semi-arid } & \multicolumn{2}{|c|}{ Humid } \\
\hline & $1980 s$ & $2000 s$ & $1980 s$ & $2000 s$ & $1980 \mathrm{~s}$ & $2000 s$ & 1980s & $2000 s$ & $1980 \mathrm{~s}$ & $2000 s$ & $1980 s$ & $2000 \mathrm{~s}$ & 1980 s & $2000 s$ & $1980 s$ & $2000 s$ & 1980s & $2000 s$ \\
\hline Pasture(\%) & 100 & 100 & 100 & 99 & 82 & 79 & 100 & 100 & 100 & 100 & 98 & 98 & 0 & 0 & 0 & 0 & 0 & 0 \\
\hline Forages(\%) & 0 & 0 & 0 & 0 & 6 & 9 & 0 & 0 & 0 & 0 & 0 & 0 & 100 & 100 & 100 & 100 & 0 & 0 \\
\hline Crop residues(\%) & 0 & 0 & 0 & 1 & 12 & 12 & 0 & 0 & 0 & 0 & 2 & 2 & 0 & 0 & 0 & 0 & 0 & 0 \\
\hline $\begin{array}{l}\text { Compounded and } \\
\text { supplement feeds(\%) }\end{array}$ & 0 & 0 & 0 & 0 & 0.04 & 0.04 & 0 & 0 & 0 & 0 & 0 & 0 & 0 & 0 & 0 & 0 & 0 & 0 \\
\hline
\end{tabular}


The water footprint for drinking and servicing estimates were taken from Mekonnen and Hoekstra (2010b).

\subsubsection{Estimating the water footprint of feed $\left(W F_{\text {feed }}\right)$}

The water footprint of an animal related to the feed consumed consists of two parts: (i) the water footprint of the various feed ingredients; and (ii) the water that is used to mix the feed ingredients:

$\mathrm{WF}_{\text {feed }}[a, s]=\sum_{p=1}^{n}\left(\right.$ Feed $\left.[a, s, p] \times \mathrm{WF}_{\text {prod }}^{*}[p]\right)+\mathrm{WF}_{\text {mixing }}[a, s]$

where Feed $_{[a, s, p]}$ is the annual amount of feed ingredient $p$ consumed by an animal in category $a$ in production system $s$ (tonne/yr) and $\mathrm{WF}_{\text {mixing }}[a, s]$ is the volume of water consumed by mixing the feed for an animal in category $a$ in production system $s$ $\left(\mathrm{m}^{3} / \mathrm{yr} / \mathrm{animal}\right) . \mathrm{WF}_{\mathrm{prod}}^{*}[p]$ is the average water footprint of the various crops, roughages and crop by-products $p\left(\mathrm{~m}^{3} / \mathrm{ton}\right)$ weighted over the production locations. All other categories of feed than supplemental and compounded feed are assumed to be produced and consumed within the production system. Supplemental and compounded feed was further characterized as consisting of maize as the main cereal. Given that maize in Kenya originates from both domestic and foreign (imported) sources, we use an average value that is weighted by the relative proportions of domestic production and imports (Mekonnen and Hoekstra, 2011).

$\mathrm{WF}_{\text {prod }}^{*}[p]=\frac{P_{[p]} \times \mathrm{WF}_{\text {prod }}[p]+\Sigma_{n_{e}} \mathrm{VWI}[p]}{P_{[p]}+\Sigma_{n_{e}} P_{n_{e}}}$

where $\mathrm{WF}_{\text {prod }}[p]\left(\mathrm{m}^{3} /\right.$ tonne) is the water footprint of feed product $p$ produced in Kenya, VWI $[p]\left(\mathrm{m}^{3} /\right.$ tonne) the virtual water import of product $p$ from the feed exporting nation $n_{e}, P_{[p]}$ the quantity of feed product $p$ in Kenya (tonne/yr) and $P_{n_{e}}$ the quantity of the imported feed product $p$ from the exporting country $n_{e}$ (tonne/yr).

\subsubsection{The water footprint of feed ingredients}

The water footprints of the various crops, roughages and crop by-products ( $\mathrm{WF}_{\mathrm{prod}}^{*}[p], \mathrm{m}^{3} /$ ton $)$ that are eaten by cattle and shoats have been calculated following the method of Hoekstra and Chapagain (2008). The water footprints of feed crops were estimated using a crop water use model that estimates crop water footprints at a $5 \times 5^{\prime}$ spatial resolution globally (Mekonnen and Hoekstra, 2011) and aggregated to the scale of the three previously described Kenyan production systems. Grey water footprints were estimated by considering only leaching and runoff of nitrogen fertilizers (Mekonnen and Hoekstra, 2010a).

\subsubsection{Land footprint of livestock products}

Our focus is mainly on production of livestock products, which includes direct use of pastures, but also the land associated with production of animal feed. Therefore, livestock production is associated with both grassland and cropland. Cropland, the most productive land use type, consists of the area required to grow all crop products. Grazing land has lower productivity than the croplands and consists of grasslands - cultivated and natural used to provide feed to animals (Borucke et al., 2013). Standard calculations of ecological footprint apply equivalence factors to standardize land types, since not all land is equally productive (Wackernagel et al., 1999; Borucke et al., 2013). The equivalence factor ensures that the total land used at the global scale will be equal to the total available land used. Our categorization of the production systems based on the agro-ecological factors, accounts for low productivity of marginal grasslands that differ from grasslands in high potential lands. Differences in yield and environmental impact on the grasslands in low and high potential lands determine the use of this resource. As we intend to assess the actual amount of land used for livestock production in Kenya, we do not apply the equivalence factors in our calculations.

We attributed land area associated with the production of feed crops to each livestock product considering (i) the feed consumed per animal, (ii) country specific yields, (iii) domestic production and import of the different feed crops. Land use associated with grass production is based on grassland production and corresponding yield in the three production systems previously outlined for Kenya. By using local yields, we ensure that the calculated area is representative of the actual area used for production in Kenya
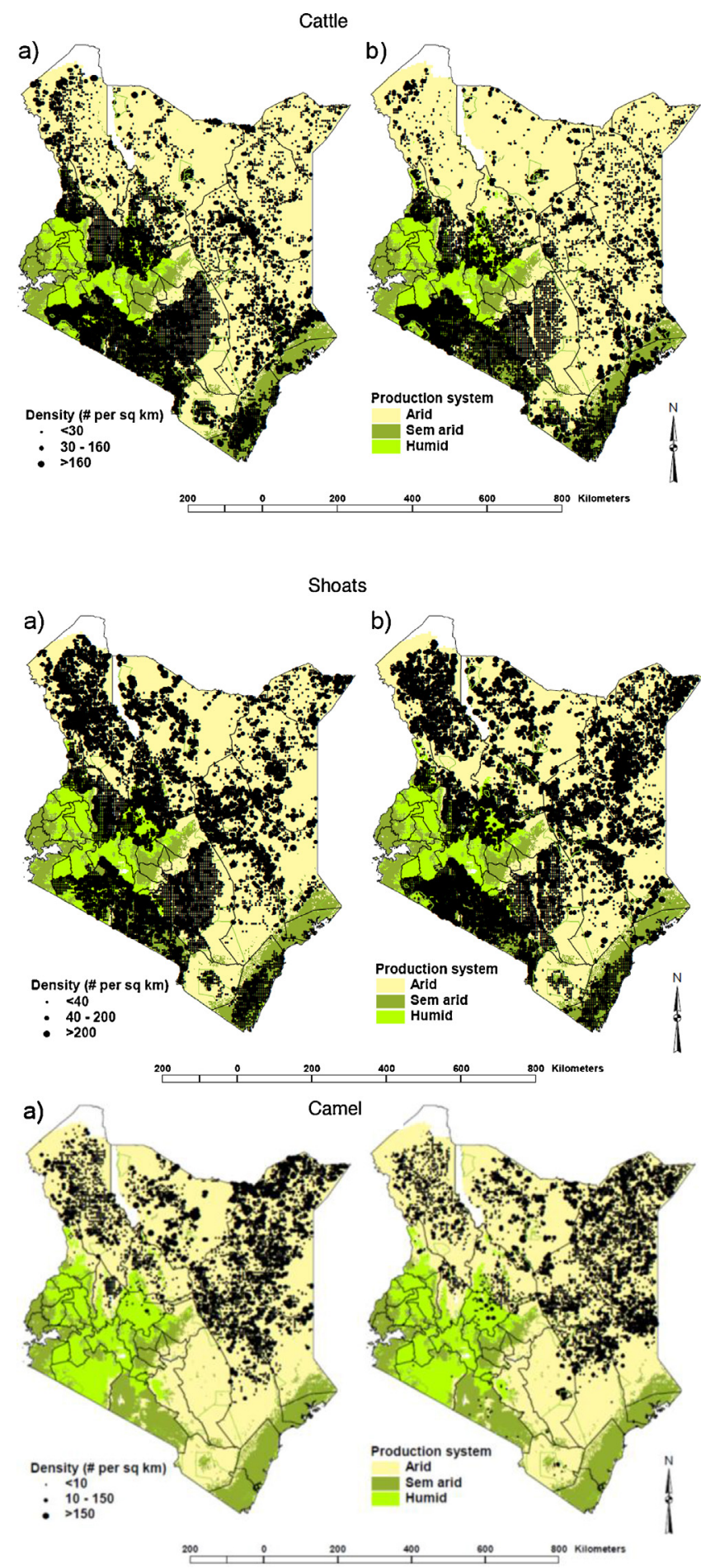

Fig. 1. Map of cattle, shoat and camel densities in Kenya in the three production systems in the (a) 1980s and (b) 2000s. 
(van Vuuren and Smeets, 2000). The land use (ha) within a production system is estimated based on the land used for domestic production minus those related to exports plus those related to imports. For all categories of feed except compounded feed and supplements, we assume that there is no import or export of these feed components from the production system. For the category of supplement and compounded feeds, that only considers maize germ as the main cereal in the feed, we use import and export values in the calculation by extending Eq. (7) as follows:

$\operatorname{Land}_{\mathrm{use}_{p, s}}=\frac{\operatorname{Prod}_{p, s}}{Y_{p, s}}+\sum_{n_{e}} \frac{\mathrm{IMP}_{p, s}}{Y_{p, n_{e}}}-\frac{\operatorname{EXP}_{p, s}}{Y_{p, s}^{*}}$

where Land_use $e_{p, s}($ ha) is land area associated with the production of feed product $p$ in production system $s$, IMP (tonne/yr) the imported quantity of feed product $p$ from exporting nation $n_{e}$, EXP (tonne/yr) the quantity of feed product $p$ exported from Kenya. $Y_{p, s}$ (tonne/ha) the annual yield of product $p$ in Kenya, $Y_{p, n_{e}}$ (tonne/ha) the yield of product $p$ in the exporting country and $Y_{p, s}^{*}$ (tonne/ha) the weighted average of local production yield and import yield. For domestically produced feed we use local yield calculations for the specific production system. For the exported products we use a weighted average yield, while for imported products, the yields of the source countries are used.

\section{Results}

3.1. Changes in the numbers and distributions of cattle and shoats in the arid, semi-arid and humid production systems

Cattle, shoat and camel densities showed opposite trends between the 1980s and 2000s as shown in Fig. 1. Cattle numbers declined by $22 \%$ in the humid and $39 \%$ in the arid production systems between the 1980s and the 2000s. However, the decline was not uniform across the production systems as cattle densities increased in parts of the semi-arid production system bordering the coastal strip. Shoat densities increased across all the production systems, with the highest increase (27\%) recorded in the semi-arid production system between the 1980s and 2000s. The highest increase in camel density was observed for the semiarid production system, where their numbers went up by $27 \%$.

\subsection{The water and land footprints of milk and meat production}

3.2.1. Total water and land footprints of meat and milk production

In both the 1980s and the 2000s, shoats outnumbered all the other species (Fig. 2). However, cattle dominated the production of meat and milk in both periods and across all the production systems. Shoat production of meat and milk in the arid production system in the 2000s was similar to that of cattle despite the fact that shoats were about four times as many. Fig. 3, presents the total water and land footprint for milk and meat production. The total water footprint of meat production was 15-44 times larger than the corresponding water footprint of milk production for all the livestock species across the production systems. The total water footprint of milk and meat production was largest in the arid production system. For cattle, the water footprint dropped dramatically between the 1980s and 2000s, except in the humid production system. However, the water footprint for shoat production showed a persistently larger water footprint in the 2000s than the 1980s.

The cattle land footprint showed an overall trend similar to that for the water footprint, with a general decrease evident between the 1980s and the 2000s. Production of meat and milk had the largest land footprint in the arid production system. Land footprint of milk production by cattle was similar between the 1980s in the arid and the 1980s and 2000s in the humid production systems. Cattle land footprint of milk and meat production in the humid production system increased by $7 \%$ and $25 \%$, respectively, despite a $22 \%$ decline in cattle numbers between the 1980s and 2000s.

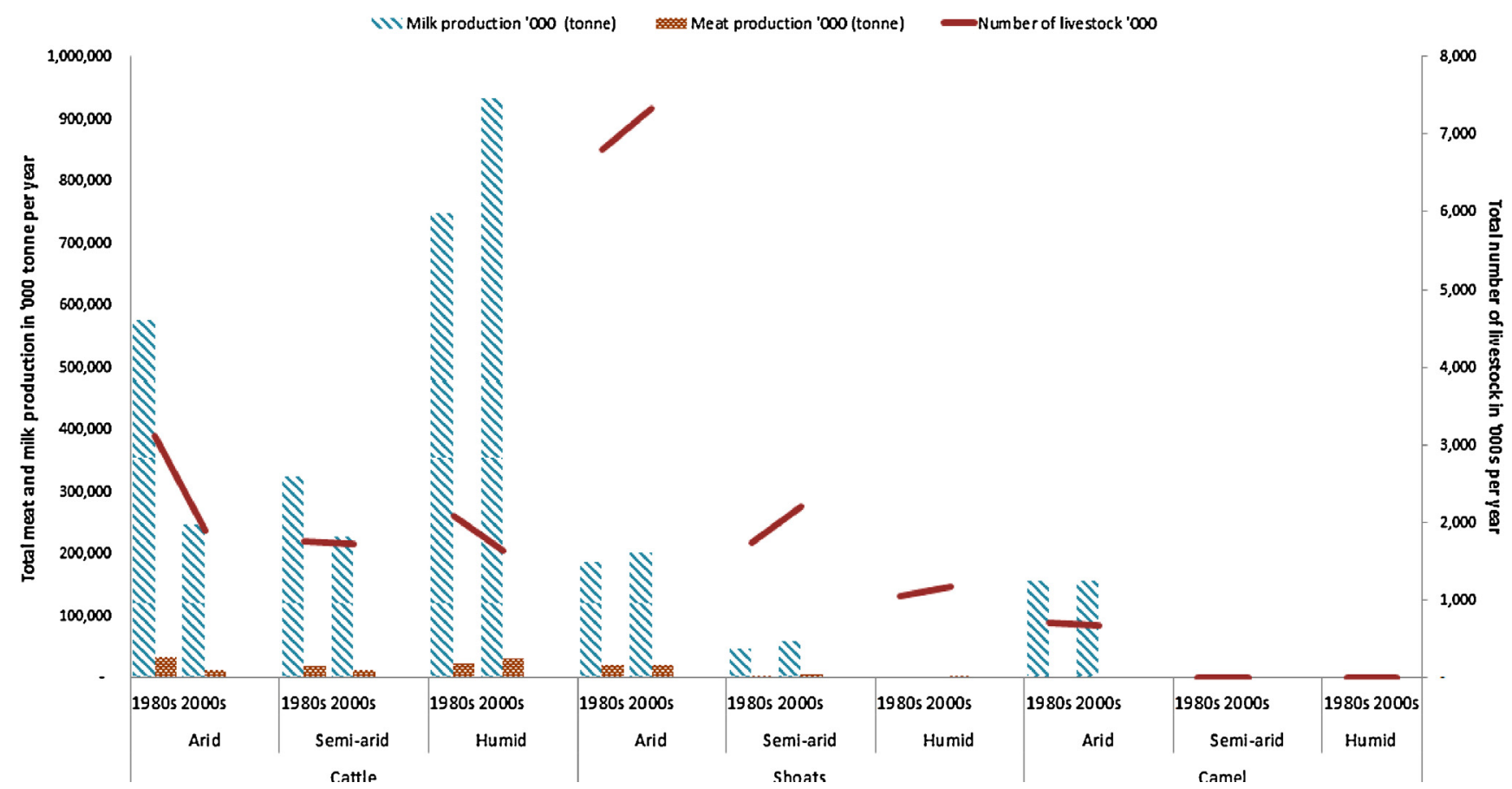

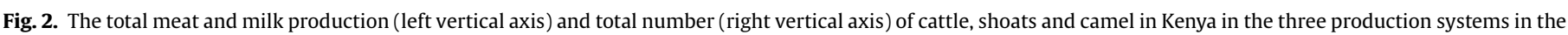
1980 s and 2000s. 
3.2.2. Contribution of green and blue water footprints to product footprint

Fig. 4 shows the proportion of green and blue water footprints per tonne of milk and meat produced. There was considerable variation in the green and blue water footprint of milk and meat across the production systems. A grey footprint is present but represents only a very small proportion of the footprint per tonne of product. The grey footprint therefore does not show in the figures and we do not carry it forward in the analysis. Milk production had a higher proportion of blue to green water footprint than meat production did. The contribution of blue water footprint to the total water footprint per tonne of milk produced ranged from $2 \%$ to $19 \%$ across all production systems. Milk production by shoats showed a higher percentage (19\%) of blue water footprint in the arid and semi-arid production system than that exhibited by milk production from cattle $(2 \%)$ in the same systems. The blue water footprint of camel milk production of $7 \%$ falls between that of cattle and shoats. The green water footprint dominated the production of meat by cattle, shoats and camels across all the three production systems. The proportion of blue water footprint out of the product total, associated with meat production ranged from 1 to $7 \%$. The increase in the water and land footprints per tonne of meat production for both cattle and shoats between the 1980s and the 2000s is mostly due to worsened feed conversion efficiency for meat production; conversely, improved feed conversion efficiency for milk production leads to reducing footprints per tonne of milk for most animal species and production systems. In the 1980s, the water footprint of milk production in the humid system was closer to that in the arid and semi-arid systems than in the 2000s. This is indicative of a similarity in breeds and feeds in all the three production systems in the 1980s. For the 2000s, there is a huge gap between the milk yield in the arid and semi-arid production systems and the humid system due to the enhanced productivity associated with breed improvement and increase in milk yield per cow, which lowered the water footprint of productionper tonne.

\subsubsection{Grazing and cropland footprint per tonne of animal product}

The grazing land footprint dominated the production of milk and meat across all production systems between the 1980s and 2000s (Fig. 4). In the arid and semi-arid production systems, the land footprint of cattle and shoat meat production increased between the 1980s and 2000s. In the humid production system, by contrast, there was a slight decrease in grazing and cropland footprints for beef production. There was a decrease in the land footprint per tonne of cow milk between the 1980s and 2000s. The grazing land footprint of beef production was about 30 times larger than that of the grazing land footprint of milk production.

The grazing land footprint of milk production by cattle was larger for the arid and semi-arid systems than for the humid production system. Similarly, cropland requirement for milk production by cattle was higher for the semi-arid than for the humid production system. Camel milk production had the largest grazing land footprint, though their feed composition was assumed to be $100 \%$ natural forage. Camel feed is defined as forage but because their range is confined to arid and semi-arid systems, we assigned their land footprint to the grazing component. In the arid and semi-arid production systems, the land footprint of a ton of camel milk was 1.3 and 18 times larger than the land footprint of cattle and shoat milk, respectively. Shoats showed the smallest land footprint in the humid production system.

\section{Discussion}

\subsection{General limitations of data and scope of conclusions}

This study is the first to quantify changes in ruminant numbers and resource use over a 30-year period in Kenya. The dearth of local

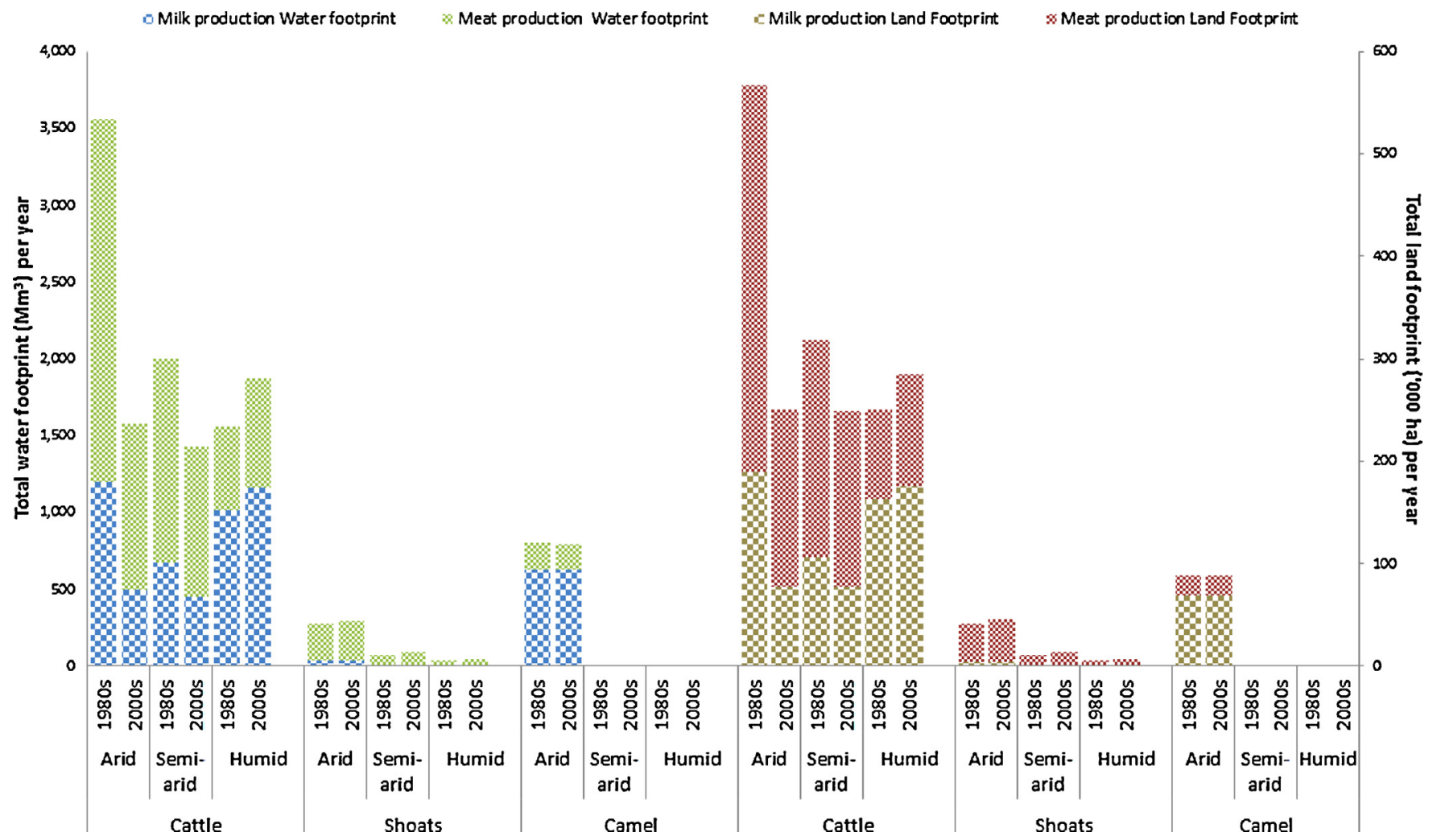

Fig. 3. The total water (left vertical axis) and land (right vertical axis) footprint of meat and milk production in Kenya in the three production systems in the 1980s and 2000 s. 
literature and relevant data on this subject has posed considerable challenges to the estimation of a number of the important parameters. We therefore only focused on two broad time periods to minimize potential biases associated with any inaccuracies in the data and assumptions we made. Consequently, we restrict our estimates of changes in livestock numbers to the data provided by the DRSRS. Other potential data sources from the government databases were not available to us due to ongoing efforts aimed at quality control and harmonization of livestock data from various sources (pers. comm). Our livestock population estimates are lower than the national estimates published by the Food and Agriculture Organization (FAOSTAT) and the 2009 Kenya national census livestock estimates. The DRSRS data have been collected consistently using the same counting techniques from 1977 to 2014 and thus cover the entire time span of our study (1977-2012). The reliability of the other available national statistics on livestock has
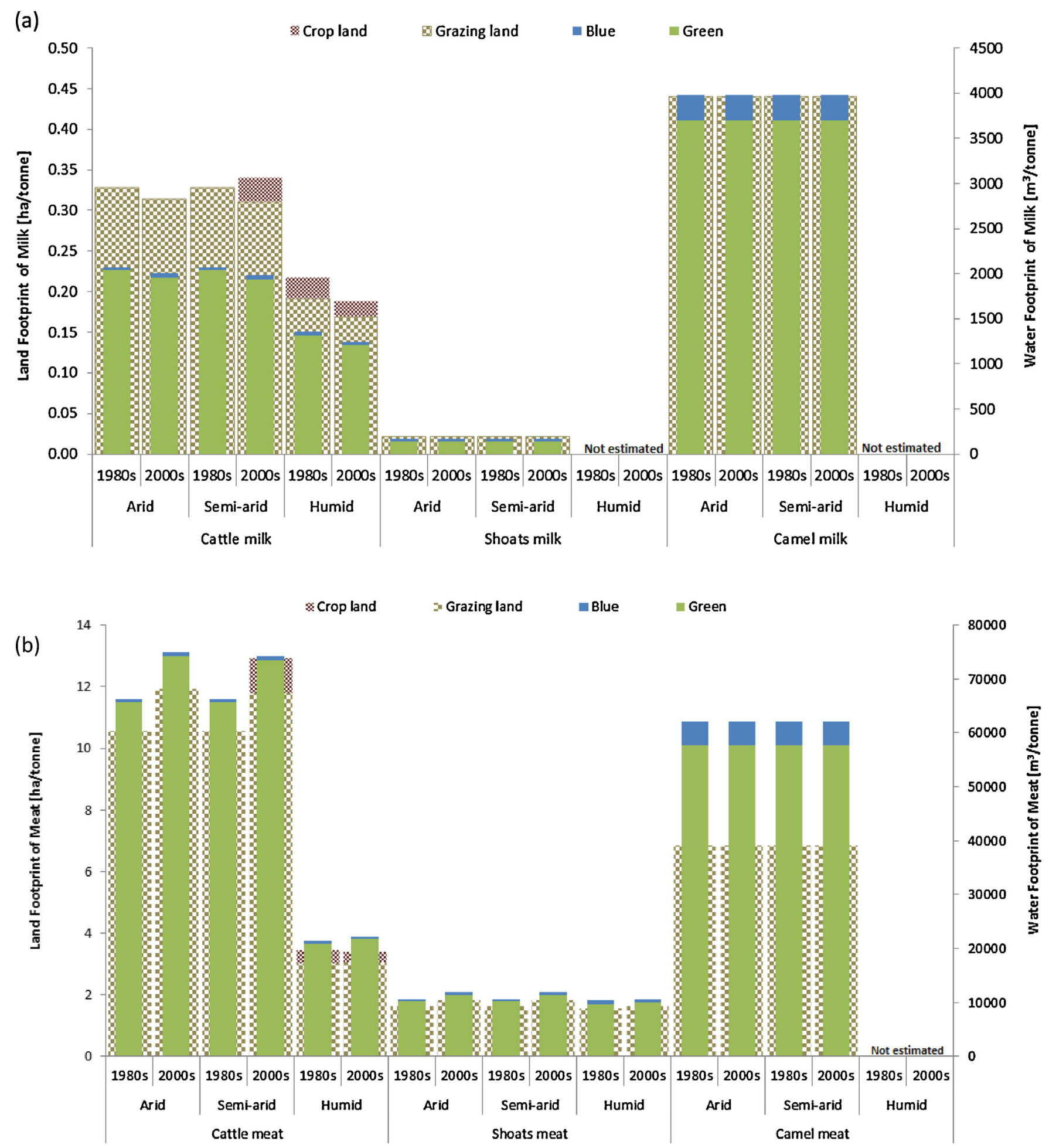

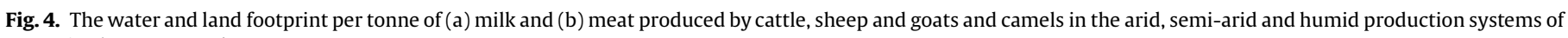
Kenya in the 1980 s and 2000s. 
not been quantified and glaring discrepancies were reported following the 2009 census. These other national livestock statistics are also not based on the same and consistent sampling methodology (Dietz et al., 2014; Robinson et al., 2014). The DRSRS data were also amenable to classification into the broad heterogeneous production systems used in this study, but this was not possible to do reliably using the other occasional data sets. Enhancing the consistency, reliability and frequency of the livestock surveys at the national level in Kenya would be necessary to ensure accuracy of future parameter estimates by similar studies looking at long term changes in the livestock production systems. We assumed that the extent of the production systems remained effectively unchanged over the 30-year study period. This assumption may have been partially violated if agro-climatic changes in some of the production systems were sufficient to engender substantial transitions in pastoral livelihood strategies (Jones and Thornton, 2009). Although quantifying and incorporating such changes in the production systems in our analysis would be desirable, doing so would add a layer of considerable complexity to the analysis and take us beyond the scope of this study. Additionally, our assumption of limited change over the 1977-2012 study period is consistent with the use of 1970-2000 as the base period for defining the livestock production systems (Robinson et al., 2011).

Our analysis focused on the biophysical processes underlying resource use and did not consider economic aspects. Additionally, the lack of consistent data sources on the changes in such parameters as feed composition and carcass and milk yields precluded computing yearly estimates of freshwater and land use.

\subsection{Combining water and land footprints to enhance assessment of resource demands for milk and meat production}

Similar patterns and developments were found for the green and blue water and the grazing and cropland footprints in meat and milk production. The reason is that water and land requirements largely go together. As a rule we can expect and we observed indeed that greater land requirements are accompanied by greater green water consumption. With a shift toward more supplement and compounded feed, we can expect a shift toward greater cropland footprint and, in case of irrigated crops, a greater blue water footprint. We did not observe such development for the historical period studied, because intensification of livestock in Kenya hardly occurred.

\subsection{Decline in cattle numbers and increased importance of shoats and camels for subsistence}

The increase in the number of shoats and concurrent decline in the number of cattle between the 1980s and 2000s, whatever its cause, points to the growing importance of small stock to the livelihoods of the Kenyan pastoral communities. The decline in cattle numbers in the arid and semi-arid production systems is reflected in the significant decrease in both the total water and land footprints of cattle production between the 1980s and 2000s. In the same vein, the increase in the number of shoats was accompanied by an increase in the total water and land footprints for shoats between 1980s and 2000s. This indicates an upsurge in the importance of shoats as a source of meat and milk. Despite their continued increase in numbers, shoats still have the lowest demand on water and land resources. This finding is both interesting and important, especially when considering options for reducing pressure on potentially scarce resources, which would favor a shift toward shoat products. The decrease in the total land and water footprint of milk and meat production by camel in the arid production system and increase in the semi-arid production system is indicative of increasing adoption of this drought resistant species by farmers in the semi-arid system. The livestock declines, especially of cattle, are linked to an increase in the frequency and severity of droughts between the 1980s and 2000s (Jones and Thornton, 2009). The increase in the number of sheep and goats, both of which use less water and land resources than cattle, in the arid and semi-arid production system, offers the livestock producers the opportunity to continue meeting their meat and milk production goals in the prevailing more arid climatic conditions.

\subsection{Dominance of cattle in freshwater and land use toward milk and meat production}

Despite their decline in total numbers, cattle still contribute most to the total meat and milk production and total water and land footprints of meat and milk production in the three Kenyan production systems. This highlights the overall importance of cattle in resource use for meat and milk production in Kenya. The trends observed in water and land use by cattle are, however, not uniform across the systems. For instance, in the semi-arid production system, the cropland footprint associated with the production of a ton of beef and milk by cattle, is much larger than that for the humid system. However, given that the quality and composition of the diet of cattle in the humid production system tends toward intensification of production by the introduction of compounded and supplemental feeds, we expect a larger cropland footprint in the future and possibly a larger blue water footprint in this system. The poor diets in the semi-arid system between the two periods, combined with the declining trend in feed conversion efficiency for meat are the main causes of this apparent larger demand for cropland. The livestock farmers focus on enhancing yield by upgrading their breeds but not also concurrently investing in feed improvement, so that feeds continue to constrain milk and meat production in the three production systems.

\subsection{Effect of productivity changes on water and land footprints}

Table 3 shows the proportion of green and blue water footprint per tonne of milk and meat produced and compares this to the work by Mekonnen and Hoekstra (2012). Our estimates for arid and semi-arid systems can best be compared to the estimates for grazing systems in Mekonnen and Hoekstra (2012), and our estimates for the humid system with their estimate for mixed systems. Our estimates of the water footprints of milk production are similar to the estimates by Mekonnen and Hoekstra (2012). Beef production showed the largest difference in values between the two, primarily due to differences in the assumed feed conversion efficiency and feed composition. We used detailed local and regional data that are a factor of two or larger than those used by Mekonnen and Hoekstra (2012). In both studies, green water was the predominant water footprint component. A larger proportion of blue water in the total water footprint with this improved productivity would be associated with the inclusion of a cropland footprint for irrigated feed production. If such improved productivity were to be realized, then the resultant increases in blue water footprints and cropland footprints for livestock production would potentially enhance competition for natural resources required for feed and food production. Our study did not include data on the industrial livestock production system in Kenya as it was deemed quantitatively negligible at the national scale of this study. The industrial production system reported in Mekonnen and Hoekstra (2012) has a water footprint of an order of magnitude lower than any of the production systems we examined. However, if it were to become prevalent, it would require more cropland than any of the systems considered in this study, with a potential 
Table 3

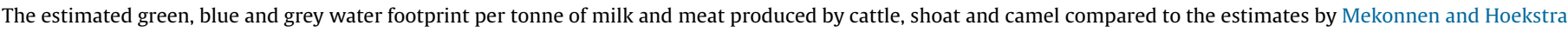
(2012).

\begin{tabular}{|c|c|c|c|c|c|c|c|c|c|c|c|}
\hline \multirow{4}{*}{$\begin{array}{l}\text { Parameters } \\
\text { Production } \\
\text { Kenya }\end{array}$} & \multicolumn{11}{|l|}{ Production system } \\
\hline & \multirow{2}{*}{ system } & \multirow{2}{*}{\multicolumn{2}{|c|}{$\begin{array}{l}\text { Grazing system } \\
\text { Mekonnen and Hoekstra, } \\
2012\end{array}$}} & \multirow{2}{*}{\multicolumn{2}{|c|}{$\frac{\text { Arid and semi-Arid }}{\text { Current study }}$}} & \multirow{2}{*}{\multicolumn{2}{|c|}{$\begin{array}{l}\text { Mixed system } \\
\text { Mekonnen and Hoekstra, } \\
2012\end{array}$}} & \multirow{2}{*}{\multicolumn{2}{|c|}{$\frac{\text { Humid }}{\text { Current study }}$}} & \multirow{2}{*}{\multicolumn{2}{|c|}{$\begin{array}{l}\text { Industrial } \\
\text { Mekonnen and Hoekstra } \\
2012\end{array}$}} \\
\hline & & & & & & & & & & & \\
\hline & Water footprint $\mathrm{m}^{3} /$ ton & Meat & Milk & Meat & Milk & Meat & Milk & Meat & Milk & Meat & Milk \\
\hline \multirow[t]{4}{*}{ Cattle } & Green & 38,370 & 1300 & 74,300 & 2000 & 10,760 & 900 & 21,800 & 1200 & 3200 & - \\
\hline & Blue & 180 & 40 & 700 & 50 & 190 & 100 & 500 & 30 & 100 & - \\
\hline & Grey & 0 & 0 & 0 & 0 & 0 & 0 & 0 & 0 & - & - \\
\hline & Total & 38,540 & 1300 & 75,000 & 2000 & 10,940 & 1000 & 22,300 & 1240 & 3300 & - \\
\hline \multirow[t]{4}{*}{ Shoats } & Green & 11,200 & & 11,500 & 140 & 5170 & & 10,000 & & 2400 & - \\
\hline & Blue & 400 & & 600 & 30 & 400 & & 600 & & 400 & - \\
\hline & Grey & 0 & & 0 & 0 & 540 & & 0 & & - & - \\
\hline & Total & 11,600 & & 12,000 & 170 & 6110 & & 10,600 & & 2800 & - \\
\hline \multirow[t]{4}{*}{ Camel } & Green & & & 577,40 & 3700 & & & & & & \\
\hline & Blue & & & 4440 & 300 & & & & & & \\
\hline & Grey & & & 0 & 0 & & & & & & \\
\hline & Total & & & 62,180 & 4000 & & & & & & \\
\hline
\end{tabular}

increase in the blue water footprint as well. Our results show that poor feed conversion efficiency has a large impact on the efficiency with which freshwater and land resources are utilized, in accord with other studies (Herrero et al., 2013). Beef production has larger water and land footprints per tonne than shoats and camel due to higher conversion efficiencies for the latter two species. Diet composition and quality also determine the magnitude of the water and land footprints of meat and milk production. Improved diets translate to better feed conversion and, eventually, to more efficient use of freshwater and land. This is demonstrated by cattle in the humid system. Their slightly better feed conversion efficiency in the 2000s relative to the 1980s mirrors the increase in the proportions of cross and pure bred cattle and of compounded and supplemental feeds. Nonetheless, the productivity of the improved cattle breeds in the humid production system is still relatively low because cattle diets have not correspondingly improved in Kenya to levels approximating those recommended for optimal yields.

\section{Conclusion and recommendations}

The demand for water and land for meat and milk production is mainly determined by the total numbers, feed conversion efficiency and diet composition of livestock. For cattle milk and meat, the study revealed that the humid production system had the smallest water and land footprints per tonne. Furthermore, the study showed that the water and land footprints for milk and meat from sheep and goats are much smaller than for cattle and camels.

There are many opportunities to improve the water and land use efficiency in meat and milk production in the arid and semiarid production systems. Interventions such as rangeland rehabilitation to improve biomass availability and diet quality and breeding to increase growth rates and carcass yields can enhance the feed conversion efficiency and, in turn, lead to efficiency gains in natural resources use. Lower water and land requirements by milk production in these systems, may support the conclusion that it is better to produce milk and not meat in the arid and semi-arid systems. However, milk production in the arid and semi-arid systems is mainly constrained by political, social and environmental impediments such as limited access to markets and inputs, including high quality feeds. Production in the humid system is the most resource efficient way to produce both cattle meat and milk. The proximity to markets and cross-breeding with exotic animals has favored the focus on milk production. Diet quality has however not developed in tandem with the improvement in breeds, thus constraining the feed conversion efficiency. Using fodder crops that can be intercropped, and crop residues that do not compete directly with food production is one way to improve the livestock diets in the humid system with low potential for conflicts. There is thus a pressing need for research focusing on advancing our understanding of the factors constraining the uptake of better feeding strategies and more investment in improved feed production.

Although cattle meat and milk in the humid system are more resource efficient than in the arid and semi-arid systems, there are many competing claims to the available land and water resources. On the other hand, in arid and semi-arid systems, there are fewer competing demands other than setting areas aside for wildlife conservation and emergence of some cropping in the semi-arid regions. We therefore think that meat production should be carried out in the arid and semi-arid areas insofar possible without conflict with crop production where viable and wildlife protection. Drought and disease resistance associated with the indigenous livestock breeds in the arid and semi-arid systems provides an added advantage to the focus on meat production in these areas. Meat production would also limit the competition with biodiversity conservation by minimizing land use changes and indigenous species losses (Renwick et al., 2014). In addition, the livestock production in the rangelands has other attendant benefits such as wealth accumulation and other cultural roles that are not captured by the purely biophysical assessment we carried out. If these alternative attributes of livestock production are incorporated, then there should be a potential further reduction in the water and land use for meat production in these systems. Finally, an understanding of the sustainability of the current meat and milk production practices and implications of attempts to optimize interaction of the production parameters governing resource use efficiency in each system would enrich our capacity to develop the most resource efficient production practices.

Using both water and land footprints as indicators can deepen our appreciation of the interplay between the management of the two key resources demanded by livestock production - land and water. Additionally, we provide empirical evidence that can enhance our understanding of the key constraints to improving the efficiency of livestock production in Kenya. Finally, our results can guide efforts aimed at improving freshwater and land use efficiency for the specific production systems we studied and possibly other similar systems elsewhere. 


\section{Acknowledgments}

CKB was funded by the NUFFIC Netherlands Fellowship Programme The contribution by MS and JdL was supported by the CGIAR Research Program on Drylands (CRP 1.1). We thank Nicholas Ndiwa, Mats Lannerstad and Ben Lukuyu for suggestions that helped improve earlier drafts of this paper. We would also like to thank two anonymous reviewers for their constructive assessment of an earlier draft of this paper.

\section{References}

Aklilu, Y., Irungu, P., Reda, A., 2002. An audit of the livestock marketing status in Kenya, Ethiopia and Sudan. Community-Based Animal Health and Participatory Epidemiology Unit, Pan African Programme for the Control of Epizootics (PACE). Organization of African Unity/Inter African Bureau for Animal Resources (AUIBAR), Nairobi

Bac, D., Badulescu, A., Lang, E., 2011. Excesses and challenges of the economic growth. A brief history: from Malthus to Al Gore. Actual Probl. Econ. 117, 281-289.

Bebe, B.O., Udo, H.M.J., Rowlands, G.J., Thorpe, W., 2003. Smallholder dairy systems in the Kenya highlands: cattle population dynamics under increasing intensification. Livest. Prod. Sci. 82, 211-221.

Behnke, R., Muthami, D., 2011. The Contribution of Livestock to The Kenyan Economy. IGAD LPI Working Paper

Bertzky, B., Corrigan, C., Kemsey, J., Kenney, S., Ravilious, C., Besançon, C., Burgess, N., 2012. Protected Planet Report 2012: Tracking Progress Towards Global Targets For Protected Areas. IUCN and UNEP-WCMC, Gland, Switzerland and Cambridge, UK

Borucke, M., Moore, D., Cranston, G., Gracey, K., Iha, K., Larson, J., Lazarus, E., Morales, J.C., Wackernagel, M., Galli, A., 2013. Accounting for demand and supply of the biosphere's regenerative capacity: the national footprint accounts' underlying methodology and framework. Ecol. Indic. 24, 518-533.

Bouwman, A.F., Van der Hoek, K.W., Eickhout, B., Soenario, I., 2005. Exploring changes in world ruminant production systems. Agric. Syst. 84, 121-153.

Campbell, D.J., Lusch, D.P., Smucker, T.A., Wangui, E.E., 2005. Multiple methods in the study of driving forces of land use and land cover change: a case study of SE Kajiado District, Kenya. Hum. Ecol. 33, 763-794.

Chapagain, A., Hoekstra, A.Y., 2003. Virtual water flows between nations in relation to trade in livestock and livestock products. Value of Water Research Report Series No. 13, Delft, Netherlands.

Chapagain, A.M., Hoekstra, A.Y., 2011. The blue, green and grey water footprint of rice from production and consumption perspectives. Ecol. Econ. 70, 749-758.

Chertow, M.R., 2000. The IPAT equation and its variants. J. Ind. Ecol. 4, 13-29.

De Leeuw, P., Rey, B., 1995. Analysis of current trends in the distribution patterns of ruminant livestock in tropical Africa. People 11, 24.

De Leeuw, P.N., Wilson, R.T., 1987. Comparative productivity of indigenous cattle under traditional management in sub Saharan Africa. Quart. J. Int. Agric. 26, 377-390.

Dietz, T., Foeken, D., Soeters, S., Klaver, W., 2014. Agricultural dynamics and food security trends in Kenya. Development Regimes in Africa Project. Overseas Development Institute, London, UK

Erb, K.-H., 2004. Actual land demand of Austria 1926-2000: a variation on ecological footprint assessments. Land Use Policy 21, 247-259.

Ewing, B.R., Hawkins, T.R., Wiedmann, T.O., Galli, A., Ercin, A.E., Weinzettel, J., SteenOlsen, K., 2012. Integrating ecological and water footprint accounting in a multiregional input-output framework. Ecol. Indic. 23, 1-8.

FAO, 2005. Kenya country report. Irrigation in Africa in Figures, AQUASTAT Survey 2005. Food and Agriculture Organisation of the United Nations, Rome, Italy

Fiala, N., 2008. Measuring sustainability: why the ecological footprint is bad economics and bad environmental science. Ecol. Econ. 67, 519-525.

Grandin, B.E., 1988. Wealth and pastoral dairy production: a case study from Maasailand. Hum. Ecol. 16, 1-21.

Greer, J., Thorbecke, E., 1986. A methodology for measuring food poverty applied to Kenya. J. Develop. Econ. 24, 59-74.

Herrero, M., Havlík, P., Valin, H., Notenbaert, A., Rufino, M.C., Thornton, P.K., Blümmel, M., Weiss, F., Grace, D., Obersteiner, M., 2013. Biomass use, production, feed efficiencies, and greenhouse gas emissions from global livestock systems. Proc. Natl. Acad. Sci. 110, 20888-20893.

Hoekstra, A., Chapagain, A., Aldaya, M., Mekonnen, M., 2011. The Water Footprint Assessment Manual: Setting The Global Standard. Earthscan, London, UK

Hoekstra, A.Y., Chapagain, A.K., 2008. The global component of freshwater demand and supply: an assessment of virtual water flows between nations as a result of trade in agricultural and industrial products. Water Int. 33, 19-32.

Hoekstra, A.Y., Hung, P., 2002. Virtual water trade. A quantification of virtual water flows between nations in relation to international crop trade. Value of water research report series, 11 . UNESCO-IHE, Delft, The Netherlands.

Hoekstra, A.Y., Wiedmann, T.O., 2014. Humanity's unsustainable environmental footprint. Science 344, 1114-1117.

Hubacek, K., Guan, D., Barrett, J., Wiedmann, T., 2009. Environmental implications of urbanization and lifestyle change in China: ecological and water footprints. J. Clean. Prod. 17, 1241-1248.
ILRI, 2010. East African Dairy Development Project Baseline Survey: Feeds and Feeding Practices. ILRI

Jolly, G., 1969. Sampling methods for aerial censuses of wildlife populations. East Afr. Agric. Forest. J. 34, 46-49.

Jones, P.G., Thornton, P.K., 2009. Croppers to livestock keepers: livelihood transitions to 2050 in Africa due to climate change. Environ. Sci. Policy 12, 427-437.

King, J.M., 1983. Livestock water needs in pastoral Africa in relation to climate and forage. Research Reports. International Livestock Centre for Africa, Addis Ababa Ethiopia

Kosgey, I., Mbuku, S., Okeyo, A., Amimo, J., Philipsson, J., Ojango, J., 2011. Institutional and Organizational Frameworks for Dairy and Beef Cattle Recording in Kenya: a Review and Opportunities for Improvement, 48. Animal Genetic Resources( Food and Agriculture Organization of the United Nations, pp. 1-11.

McMichael, A.J., Butler, C.D., 2011. Promoting global population health while constraining the environmental footprint. Ann. Rev. Public Health 32, 179-197.

Mekonnen, M.M., Hoekstra, A.Y., 2010a. A global and high-resolution assessment of the green, blue and grey water footprint of wheat. Hydrol. Earth Syst. Sci. 14, $1259-1276$.

Mekonnen, M.M., Hoekstra, A.Y., 2010b. The Green, Blue and Grey Water Footprints of Farm Animals and Animal Products. UNESCO-IHE Institute for Water Education

Mekonnen, M.M., Hoekstra, A.Y., 2011. The green, blue and grey water footprint of crops and derived crop products. Hydrol. Earth Syst. Sci. 15, 1577-1600.

Mekonnen, M.M., Hoekstra, A.Y., 2012. A global assessment of the water footprint of farm animal products. Ecosystems 15, 401-415.

Changes in Land Use and Land Cover: A Global Perspective. In: Meyer, B.M., Turner B.L. (Eds.), Press Syndicate of the University of Cambridge, Great Britain

Monfreda, C., Wackernagel, M., Deumling, D., 2004. Establishing national natural capital accounts based on detailed Ecological Footprint and biological capacity assessments. Land Use Policy 21, 231-246.

Moran, D.D., Wackernagel, M., Kitzes, J.A., Goldfinger, S.H., Boutaud, A., 2008. Measuring sustainable development - nation by nation. Ecol. Econ. 64, 470-474.

Ndambi, O.A., Hemme, T., Latacz-Lohmann, U., 2007. Dairying in Africa - status and recent developments. Livest. Res. Rural Develop. 19 Article \#111. Retrieved March 9, 2015, from http://www.lrrd.org/lrrd19/8/ndam19111.htma

Ngigi, M., 2005. The case of smallholder dairying in Eastern Africa.

Norton-Griffiths, M., 1975. Counting Animals. African Wildlife Leadership Foundation

Oago, D.O., Odada, E.O., 2007. Sediment impacts in Africa's transboundary lake/river basins: case study of the east African great lakes. Aquat. Ecosyst. Health 10, 23-32.

Ogutu, J., Piepho, H.-P., Said, M., Ojwang', G., Kifugo, S.C., Wargute, P.W., Njino, L.W., 2015. Extreme wildlife declines and concurrent increase in livestock numbers in Kenya rangelands. PLoS One. In press

Onono, J.O., Wieland, B., Rushton, J., 2013. Productivity in different cattle production systems in Kenya. Trop. Anim. Health Product. 45, 423-430.

Ottichilo, W.K., Grunblatt, J., Said, M.Y., Wargute, P.W., 2000. Wildlife and livestock population trends in the Kenya rangeland. Wildlife Conservation by Sustainable Use. Springer, pp. 203-218.

Ouda, J.O., 2001. Feeding and care of livestock. Managing Dryland Resources. A Manual for Eastern and Southern Africa. International Institute for Rural Reconstruction (IIRR)

Ouma, E., Staal, S., Omore, A., Wanjohi, P., Njoroge, L., Njubi, D., 2000. Consumption Patterns of Dairy Products in Kenya. KARI/MoARD/ILRI Report

Owen, E., Smith, T., Steele, M., Anderson, S., Duncan, A., Herrero, M., 2004 Responding To The Livestock Revolution: The Role Of Globalisation and Implications For Poverty Alleviation. Nottingham University Press

Rangeland Management and Ecology in East Africa. In: Pratt, D.J., Gwynne, M.D. (Eds.), Hodder and Stoughton, London

Rees, W., Wackernagel, M., 1996. Urban ecological footprints: why cities cannot be sustainable - and why they are a key to sustainability. Environ. Impact Assess. Rev. 16, 223-248.

Rege, J., 2001. Zebu cattle of Kenya: Uses, performance, farmer preferences, measures of genetic diversity and options for improved use. ILRI (aka ILCA and ILRAD).

Renwick, A.R., Vickery, J.A., Potts, S.G., Bolwig, S., Nalwanga, D., Pomeroy, D.E., Mushabe, D., Atkinson, P.W., 2014. Achieving production and conservation simultaneously in tropical agricultural landscapes. Agric. Ecosyst. Environ. 192, 130-134.

Ridoutt, B.G., Sanguansri, P., Harper, G.S., 2011. Comparing carbon and water footprints for beef cattle production in Southern Australia. Sustainability 3, 2443-2455.

Robinson, T., Thornton, P., Franceschini, G., Kruska, R., Chiozza, F., Notenbaert, A. Cecchi, G., Herrero, M., Epprecht, M., Fritz, S., 2011. Global Livestock Production Systems. Food and Agriculture Organization of the United Nations (FAO)

Robinson, T.P., Wint, G.R.W., Conchedda, G., Van Boeckel, T.P., Ercoli, V., Palamara, E. Cinardi, G., D'Aietti, L., Hay, S.I., Gilbert, M., 2014. Mapping the global distribution of livestock. Plos One 9, e96084.

Staal, S., Owango, M., Muriuki, H., Kenyanjui, M., Lukuyu, B., Njoroge, L., Njubi, D. Baltenweck, I., Musembi, F., Bwana, O.,2001. Dairy systems characterisation of the greater Nairobi milk shed. Smallholder Dairy Project (SDP (R \& D)), MALDM, KARI, ILRI.

Thorpe, W., Muriuki, H., Omore, A., Owango, M., Staal, S., 2000. Dairy development in Kenya: the past, the present and the future. 
van Vuuren, D.P., Smeets, E.M.W., 2000. Ecological footprints of Benin, Bhutan, Costa Rica and the Netherlands. Ecol. Econ. 34, 115-130.

Vanham, D., Bidoglio, G., 2013. A review on the indicator water footprint for the EU28. Ecol Indic. 26, 61-75.

Wackernagel, M., Monfreda, C., Erb, K.-H., Haberl, H., Schulz, N.B., 2004. Ecological footprint time series of Austria, the Philippines, and South Korea for 1961-1999: comparing the conventional approach to an 'actual land area' approach. Land Use Policy 21, 261-269.

Wackernagel, M., Onisto, L., Bello, P., Callejas Linares, A., Susana López Falfán, I., Méndez Garcı'a, J., Isabel Suárez Guerrero, A., Guadalupe Suárez Guerrero, M.
1999. National natural capital accounting with the ecological footprint concept. Ecol. Econ. 29, 375-390.

Waithaka, M., Thornton, P., Herrero, M., Shepherd, K., 2006. Bio-economic

evaluation of farmers' perceptions of viable farms in western Kenya. Agric. Syst. $90,243-271$.

Zoumides, C., Bruggeman, A., Hadjikakou, M., Zachariadis, T., 2014. Policy-relevant indicators for semi-arid nations: the water footprint of crop production and supply utilization of Cyprus. Ecol. Indic. 43, 205-214. 